\title{
Molecular Analysis of Selected Aromatic Rice Germplasm Lines for Known Bacterial Blight Resistance Genes
}

\author{
Narinder Singh ${ }^{1}$, Renu Khanna ${ }^{1}$, Kumari Neelam², Meenakshi Mittal ${ }^{1 *}$, \\ Jagjit Singh Lore ${ }^{1}$, Rupinder Kaur ${ }^{1}$ and Kuldeep Singh ${ }^{2}$ \\ ${ }^{1}$ Department of Plant Breeding and Genetics, ${ }^{2}$ School of Agricultural Biotechnology, \\ Punjab Agricultural University, Ludhiana-141004, Punjab, India \\ *Corresponding author
}

\section{A B S T R A C T}

\section{Keywords}

Aromatic rice, Bacterial blight, Molecular marker, Resistance genes, Xanthomonas oryzae pv oryzae

Article Info

Accepted:

12 February 2019 Available Online: 10 March 2019
Molecular analysis of 30 aromatic lines revealed presence of $X a 4, x a 5$ and $x a 13$ in twelve, two and five germplasm lines, respectively. Moreover, only $x a 5+x a 13$ gene combination was found to be present in two lines. Germplasm lines, ANP -44 (RAU 3073) and ANP-204 (Improved Pusa Basmati) showed presence of $x a 5$ and xa13. Nine lines namely ANP-70 (ASGPC 14), ANP-143 (UPRI 93-101), ANP144 (Khazia Dhan), ANP-176 (Shyam Jeera), ANP-317 (R-1498-747-358-2-1), ANP -323 (NDR 8497-2), ANP-445 (Jao Mali), ANP-526 (IR 74717-3-3-1-3) and ANP-536 (IET 13548) did not contain any of the genes tested but as they impart resistance against different pathotypes so, they might contain some other known gene(s). The information generated will be helpful in accelerating elite breeding program including pyramiding of different disease resistance genes in basmati varieties.

\section{Introduction}

Rice is the staple food of almost half of the world's population. More than $90 \%$ of rice is grown in Asian countries, such as China, Japan, India, Pakistan, Vietnam and Thailand (Sumithra et al., 2012). Among the biotic stress affecting rice, bacterial blight (BB) caused by Xanthomonas oryzae pv. oryzae $(\mathrm{Xoo})$ is a major devastating disease that limit rice yields significantly across the world $(\mathrm{Ou}$, 1985; Mew et al., 1993) and limits rice production up to $81 \%$ in countries like India (Kumar et al., 2012). Aromatic rice constitutes a small but special group of rice which is considered best in quality. Among the aromatic rice, basmati has more demand in international market due to its unique features. Basmati rice is highly favored and fetches higher prices in world markets due to its special taste, aroma and flavor. Diseases, insects and weeds cause as much as 25 percent yield losses annually in cereal crops (Khush 2005). Basmati, besides being a natural low 
yielder, has a number of other constraints like abiotic and biotic factors which limit crop productivity. In India, the losses in grain yield of aromatic rice due to disease and insect pests are as high as 35 per cent (Siddiq 1993). Out of these diseases, bacterial blight (BB) caused by the pathogen Xanthomonas oryzae pv. oryzae (Xoo) is one of the most destructive diseases of rice throughout the world and causes as much as $80 \%$ yield reduction (Arunakumari et al., 2016). This disease can cause yield losses up to 60-70 per cent in the Punjab state during the epiphytotic years (Raina et al., 1981). Breeding for BB resistance is the only effective, economical and eco-friendly strategy for the management of this disease. To date, at least $38 \mathrm{BB}$ resistance genes conferring host resistance against various strains of Xoo have been identified (Bhasin et al., 2012 2012). In basmati germplasm, however, there are few reports for resistance to $\mathrm{BB}$ disease (Singh et al., 2004) which has necessitated the transfer of resistance genes from non- basmati sources (Bhatia et al., 2011), which often leads to deterioration of quality characteristics and consumer acceptability. It is therefore, essential to search useful and diverse gene(s) within aromatic germplasm available in the country. Tremendous progress has been made in mapping many agriculturally important genes with DNA markers in many crop plants (Mohan et al., 1997). These molecular markers linked to known BB resistance genes can be used for surveying the presence of different genes and this information can be subsequently exploited in the improvement. In Punjab, no single gene is effective against all the prevalent ten pathotypes of $\mathrm{BB}$ pathogen. Bacterial blight resistant genes like $X a 4, x a 5$, xa13, Xa38 in combination are more effective and durable. A set of 30 aromatic rice lines was screened against two pathotypes of bacterial blight to identify potential donors and characterized for presence of known BB genes using molecular markers.

\section{Materials and Methods}

\section{Plant material}

The plant material comprised of a set of aromatic rice lines. These lines were evaluated against two predominant pathotypes $\mathrm{PbXo}-7$ and $\mathrm{PbXo}-8$ of bacterial blight pathogen at maximum tillering stage under artificial inoculation conditions Cultivars Basmati 386 and IRBB60 were used as susceptible and resistant check, respectively. Data was recorded as per SES on 0-9 scale (IRRI, 1996).

\section{Extraction of DNA}

DNA from selected material was isolated following a CTAB based DNA extraction method as follows (Murray and Thomson, 1980). Quantification of nucleic acids was performed by using NanoDrop ${ }^{\mathrm{TM}} 1000$ spectrophotometer (ThermoScientific, Wilmington, USA) and the quality of DNA was checked by agarose gel electrophoresis. Finally the concentration of DNA was adjusted to make the working concentration of $25 \mathrm{ng} / \mu \mathrm{l}$.

\section{PCR amplification}

In vitro amplification using Polymerase Chain Reaction (PCR) was performed in an Eppendorf master cycler for confirmation of $X \mathrm{a} 4, x a 5$ and $\mathrm{x} a 13$ genes. Standard lines with known presence of these genes were used as checks. PCR analysis was carried out using Xa4 (Wang et al., 2001), xa5 (IRRI personal communication) and $x a 13$ (Sundaram et al., 2008) gene-linked primers.

\section{Visualization of PCR amplified product}

The amplified product for $\mathrm{Xa} 4$ was visualized by electrophoresis on 4 percent agarose gel while rest two primers were resolved on 1.5 
percent agarose gel. The scoring of test material was done accordingly. Test entries carrying the resistant band of appropriate size were classified as positive for the particular gene while the lines showing the susceptible band were classified as negative for that particular gene.

\section{Results and Discussion}

Against $\mathrm{PbXo}-7$, out of 30 lines tested, 18 lines showed resistant to moderately resistant reaction (1-5) while the rest of lines were susceptible (Table 1). On the other hand against $\mathrm{PbXo}-8,12$ lines exhibited resistant to moderately susceptible reaction. About 9 lines showed resistance against both the pathotypes. High level of resistance was shown by ANP44, ANP-154, ANP-155, ANP-204, ANP-445 against $\mathrm{PbXo}-7$ and ANP-144, ANP-154 and ANP-155 against pathotype $\mathrm{PbXo}-8$. Ten lines namely ANP-44, ANP-143, ANP-144, ANP154, ANP-155, ANP-203, ANP-204, ANP205, ANP-219 and ANP-317 showed high to moderate level of resistance against both the pathotypes studied. The resistance in these lines may be either due to known genes or combination of known genes or as yet undescribed gene(s). ANP-154 and ANP-155 are resistant derivative lines of Basmati 386 and Basmati 370. According to Bhatia et al., (2011), they transferred $x a 13, X a 21$ and $s d 1$ genes in Basmati 386 and Basmati 370. ANP154 (RYT 3267) was later released as Punjab Basmati 3 variety (Singh et al., 2014a). In basmati germplasm however there are few reports for resistance to $\mathrm{BB}$ (Singh et al., 2004) and only few resistant donors in basmati are known. Similar results for evaluation of aromatic rice germplasm have been shown by Singh et al., (2014b). Punjab Basmati 3 is reported to carry $x a 13+X a 21$ (Singh et al., 2014a). Rajpurohit et al., (2011) reported that pyramiding of more than one major resistance gene has proven to deliver durable resistance against BB disease. The information gained will be useful in basmati breeding programme for bacterial blight resistance.

The total 30 selected germplasm lines and two controls namely Basmati 386 (negative control), IRBB 60 (positive control). The details of these are given in Table 1. IRBB 60 is known to carry combination of four genes i.e. $X a 4+x a 5+x a 13+X a 21$ (Laon et al., 2006). $\mathrm{BB}$ resistance gene $\mathrm{Xa} 4$ was first characterized in the rice variety TKM 6 on long arm of rice chromosome 11 (Wang et al., 2001). Amplification of sequence tagged site (STS) marker MP4 which is linked to Xa4 gene revealed the presence of a $150 \mathrm{bp}$ fragment specific for $\mathrm{Xa} 4$ mediated $\mathrm{BB}$ resistance in the positive control IRBB 60 and 120bp fragment corresponding to the negative control Basmati 386. This could be easily resolved on $4 \%$ agarose gel using 50bp DNA ladder. Based on the banding pattern of germplasm lines, BB resistance gene $\mathrm{Xa4}$, was found to be present in twelve lines namely ANP -37 (Sonachoor), ANP -62 (IGSR-2-1-6), ANP -124 (CB 06550), ANP -203 (Rajendra Basmati), ANP 207 (Pusa 834), ANP -218 (IET 22289), ANP -219 (1601-105-1-46-1-1), ANP -222 (IET22778), ANP 227 (Sumati), ANP -239 (NWGR 3045), ANP -254 (Mugad Sugandh) and ANP -498 (Mugad Sugandha) as shown in Table 1 while the remaining 18 germplasm lines were found to be without $\mathrm{Xa} 4$ lines. Bacterial blight resistance gene $\mathrm{Xa} 4$ is one of the most widely exploited resistance gene in many rice breeding program (Sun et al., 2003). According to Khush et al., (1989), the exploitation of gene $\mathrm{Xa} 4$ resulted in development of many $\mathrm{BB}$ resistant rice cultivars that played significant role in protecting rice from Xoo. But presently, this gene alone is ineffective but shows resistance when present in combination. It has been reported by many workers that the pyramided lines with $\mathrm{Xa} 4$ and other bacterial blight resistance genes showed a wider spectrum and a higher level of resistance than the lines with 
single resistance gene (Huang et al., 1997; Zheng et al., 1998, Arif et al., 2008). This implies that these 12 germplasm lines are source of $\mathrm{Xa} 4$ and can be transferred to different basmati breeding lines during crossing and breeding procedure.

Screening of recessive $x a 5$ resistance gene by the amplification of microsatellite markers specific for resistant as well susceptible allele at $190 \mathrm{bp}$ revealed presence of $x a 5$ only in two germplasm lines (Table 1) namely ANP-44 (RAU 3073) and ANP-204 (Improved Pusa Basmati). The bacterial blight resistance gene $x a 5$ has been mapped on chromosome 5 with restriction fragment length polymorphism (RFLP) markers RG556 and RZ390 and microsatellite markers RM122 and RM390 (Blair and McCouch, 1997). Ramalingam et al., (2001) performed similar type of molecular survey for the presence of bacterial blight resistance genes $x a 5, x a 13$ and $\mathrm{Xa21}$ in Chinese rice germplasm. Naveed et al., (2010) also detected xa5 gene in Pakistani germplasm including Basmati varieties.

Similarly, the amplified product with primer xal3promoter ( $x a 13$ gene) from resistant line IRBB 60 was of $500 \mathrm{bp}$, while that from susceptible lines was about $300 \mathrm{bp}$ which could be easily resolved on $2.5 \%$ agarose gel by using standard 50bp DNA ladder to confirm proper size of amplified product. Based on the banding pattern of germplasm lines, it was observed that in case of xal3 BB resistance gene, only ANP-155 (RYT 3275), ANP-204 (Improved Pusa Basmati), ANP-309, ANP-44 (RAU 3073) and ANP-154 (RYT 3267) germplasm lines showed presence of the gene (Fig. 1). The recessive resistance gene, xal3 was first characterized in rice variety $\mathrm{BJ} 1$ and fine mapped to a genomic region $\sim 4 \mathrm{cM}$ on long arm of chromosome 8 (Sanchez et al., 1999). The gene linked markers MP4 linked to Xa4 (Wang et al., 2001), ' $x a 5 \mathrm{R}$ ' and xa5 S' linked to $x a 5$ (IRRI, personal communication) and $x a 13$ promoter' linked to $x a 13$ (Sundaram et al., 2008) were used to select lines carrying $\mathrm{Xa4}, \mathrm{xa} 5$ and $x a 13$ genes, respectively. The details of amplification pattern of selected lines and checks for $\mathrm{Xa4}, x a 5$ and $x a 13$ genes are given in Table 1.

Out of 30 germpalsm lines tested, only two lines showed presence of combination of $x a 5+x a 13$ namely ANP-44 (RAU 3073) and ANP-204 (Improved Pusa Basmati). Goel et al., (1998) reported that none of the known genes were fully effective against all the pathotypes of $\mathrm{BB}$ pathogen from northern India.

Similar work has been reported by Mangat $e t$ al., (2012) and Khanna et al., (2014) in which they identified $\mathrm{Xa4}, \mathrm{xa} 13$ and $\mathrm{Xa21}$ genes through molecular analysis in elite non basmati rice breeding lines and showed effectiveness of multiple BB resistance genes in rice varieties. Sombunjitt et al., (2017) identified Xa-resistance genes such as $\mathrm{Xa} 4$, $x a 5, X a 7$ and $x a 13$ using PCR-based genelinked and gene-specific markers in Thai local rice germplasm.

The narrow genetic base of cultivated rice will cause vulnerability to BB because of an increased frequency of newly evolved pathotypes of greater virulence. As a result, increasing attention is needed to focus on the accumulation of major disease resistance genes in crop plants. Pyramided lines carrying more resistance genes showed broad spectrum and higher resistance than the lines with a single resistance gene (Suh et al., 2009, 2013). Fourteen lines did not contain any of the known genes tested i.e. Xa4, xa5 and $x a 13$. Out of these, nine lines namely ANP-70 (ASGPC 14), ANP-143 (UPRI 93-101), ANP144 (Khazia Dhan), ANP-176 (Shyam Jeera), ANP-317 (R-1498-747-358-2-1), ANP -323 (NDR 8497-2), ANP-445 (Jao Mali), ANP526 (IR 74717-3-3-1-3) and ANP-536 (IET 13548) impart resistance against different pathotypes. 
Table.1 Reaction of aromatic germplasm lines against two BB pathotypes and molecular analysis showing presence (+) and absence (-) of Xa4, xa5 and xa13 gene

\begin{tabular}{|c|c|c|c|c|c|c|c|}
\hline $\begin{array}{l}\text { S. } \\
\text { No. }\end{array}$ & $\begin{array}{l}\text { ANP } \\
\text { Number }\end{array}$ & & PbXo-7 & PbXo-8 & Xa4 & xa5 & xa13 \\
\hline 1. & ANP-37 & Sonachoor & $6 \pm 1.41$ & $6 \pm 1.41$ & + & - & - \\
\hline 2 & ANP-43 & Kankjeer & 7 & 9 & - & - & - \\
\hline 3 & ANP-44 & RAU 3073 & $2 \pm 1.41$ & $4 \pm 1.41$ & - & + & + \\
\hline 4 & ANP-62 & IGSR-2-1-6 & $6 \pm 1.41$ & 7 & + & - & - \\
\hline 5 & ANP-70 & ASGPC 14 & 5 & 7 & - & - & - \\
\hline 6 & ANP-124 & CB 06550 & 5 & $6 \pm 1.41$ & + & - & - \\
\hline 7 & ANP-143 & UPRI 93-101 & 5 & $4 \pm 1.41$ & - & - & - \\
\hline 8 & ANP-144 & Khazia Dhan & 5 & 3 & - & - & - \\
\hline 9 & ANP-154 & RYT 3267 & 1 & 1 & - & - & + \\
\hline 10 & ANP-155 & RYT 3275 & $2 \pm 1.41$ & $2 \pm 1.41$ & - & - & + \\
\hline 11 & ANP-176 & Shyam Jira & 9 & 5 & - & - & - \\
\hline 12 & ANP-203 & $\begin{array}{l}\text { Rajendra } \\
\text { Basmati }\end{array}$ & $4 \pm 1.41$ & 5 & + & - & - \\
\hline 13 & ANP-204 & $\begin{array}{l}\text { Improved Pusa } \\
\text { Basmati }\end{array}$ & 3 & 5 & - & + & + \\
\hline 14 & ANP-207 & Pusa 834 & 5 & 5 & + & - & - \\
\hline 15 & ANP-218 & IET 22289 & 5 & $6 \pm 1.415$ & + & - & - \\
\hline 16 & ANP-219 & $\begin{array}{l}\text { 1601-105-1-46- } \\
1-1\end{array}$ & $4 \pm 1.41$ & 5 & + & - & - \\
\hline 17 & ANP-222 & $\begin{array}{l}\text { IET22778 } \\
(1596-121-148)\end{array}$ & $6 \pm 1.41$ & 5 & + & - & - \\
\hline 18 & ANP-227 & Sumati & $6 \pm 1.41$ & 7 & + & - & - \\
\hline 19 & ANP-239 & NWGR 3045 & $6 \pm 1.41$ & 7 & + & - & - \\
\hline 20. & ANP-254 & Mugad Sugandh & 5 & 7 & + & - & - \\
\hline 21. & ANP-310 & Pusa Sugandh 2 & 7 & 9 & - & - & - \\
\hline 22 & ANP-317 & $\begin{array}{l}\text { R-1498-747- } \\
358-2-1\end{array}$ & 5 & $4 \pm 1.41$ & - & - & - \\
\hline 23 & ANP-323 & $\begin{array}{l}\text { R1432-261-105- } \\
2-1-2\end{array}$ & 5 & 9 & - & - & - \\
\hline 24 & ANP-350 & Basmati 140 & 9 & 9 & - & - & - \\
\hline 25 & ANP-445 & Jao Mali & $3.5 \pm 0.71$ & $6 \pm 1.41$ & - & - & - \\
\hline 26 & ANP-480 & Bahurupi & 7 & 9 & - & - & - \\
\hline 27 & ANP-496 & Jagithyal Sanalu & $6 \pm 1.41$ & 9 & - & - & - \\
\hline 28 & ANP-498 & $\begin{array}{l}\text { Mugad } \\
\text { Sugandha }\end{array}$ & $6 \pm 1.41$ & 9 & + & - & - \\
\hline 29 & ANP-526 & $\begin{array}{l}\text { IR 74717-3-3-1- } \\
3\end{array}$ & 5 & 9 & - & - & - \\
\hline \multirow[t]{3}{*}{30} & ANP-536 & IET 13548 & 5 & 9 & - & - & - \\
\hline & $\begin{array}{l}\text { Susceptible } \\
\text { Check }\end{array}$ & Basmati 386 & 9 & 9 & - & - & - \\
\hline & $\begin{array}{l}\text { Resistant } \\
\text { Check }\end{array}$ & IRBB-60 & 1 & 1 & + & + & + \\
\hline
\end{tabular}


Fig.1 Banding patterns showing presence and absence of xa13 gene in selected aromatic germplasm lines amplified 500bp and 3000bp fragments respectively. Lane M=50bp DNA ladder, Lane $\mathrm{R}=\mathrm{IRBB} 60$, Lane $\mathrm{S}=\mathrm{Bas} 386$, Lane 1-22= selected germplasm lines and Lane $\mathrm{C}=$ control

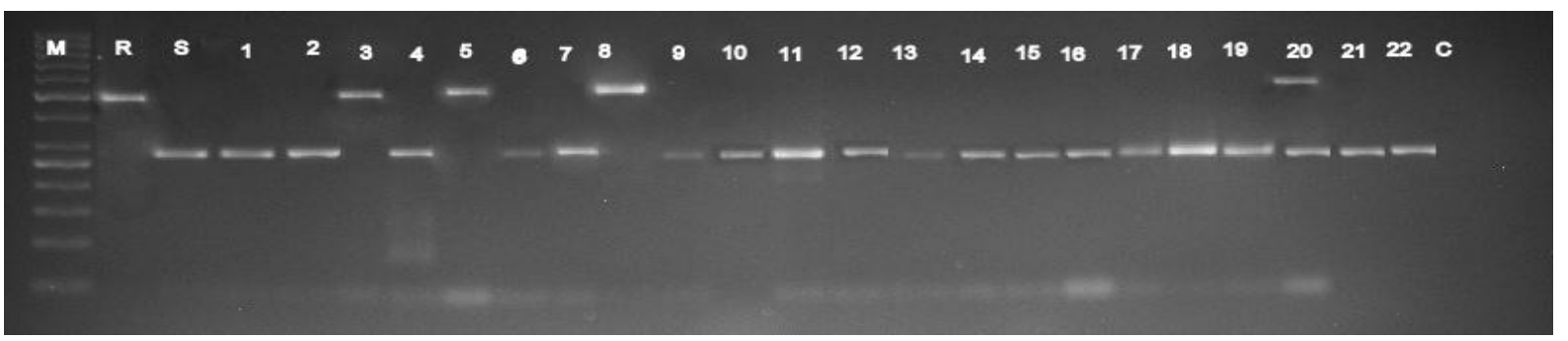

So, it is suggested that they either contain some other known gene(s) or undescribed genes. Several BB resistance genes have been identified and characterized in non- aromatic rice and incorporated and pyramided through MAS to develop resistant cultivars (Perumalsammy et al., 2010, Rajpurohit et al., 2011, Singh et al., 2014a). The information emanating from this work will help to utilize the aromatic lines for basmati breeding program directed towards pyramiding different disease resistant genes without compromising aroma and quality.

\section{Acknowledgement}

Financial support provided by the Department of Biotechnology, Government of India is gratefully acknowledged.

\section{References}

Arif M, Jaffar M, Babar M, and Sheikh A M 2008. Identification of bacterial blight resistance genes $\mathrm{Xa} 4$ in Pakistani rice germplasm using PCR. Afr J Biotechnol 7: 541-545.

Arunakumari K, Durgarani CV, Satturu V, Sarikonda K R, Chitoor, P D R, Vutukuri B, Laha G S, Nelli A P K, Gattu S, Jamal M, Prasadbabu A, Hajra S. and Sundaram, R.M. 2016. Marker Assisted Pyramiding of Genes Conferring Resistance Against Bacterial
Blight and Blast Diseases into Indian Rice Variety MTU1010. Rice Science 23, 306-316.

Bhasin, Hemal, Bhatia, Dharminder, Raghuvanshi, Saurabh, Lore, Jagjit, S., Sahi, Gurpreet K., Gill, Baljeet, Vikal, Yogesh, Singh, Kuldeep. 2012. New PCR-based sequence-tagged site marker for bacterial blight resistance gene Xa38 of rice. Molecular Breeding. 30, 607611.

Bhatia, D., Sharma, R., Vikal, Y., Mangat, G. S., Mahajan, R., Sharma, N., Lore, J. S., Singh, N., Bharaj, T. S. and Singh, K. 2011. Marker assisted development of bacterial blight resistant, dwarf, and high yielding version of two traditional basmati rice cultivars. Crop Sci. 51, 759-770.

Blair, M. W. and McCouch, S. R. 1997. Microsatellite and sequence tagged site markers diagnostic for the rice bacterial leaf blight resistance gene $X a 5$. Theor. Appl. Genet. 252, 597-607.

Goel R K, Kaur L and Saini R G 1998. Effectiveness of different $\mathrm{Xa}$ genes against Xanthomonas oryzae pv. oryzae population causing bacterial blight of rice in Punjab (India). Rice Gen. News 15: $131-133$.

Huang N, Angeles E R. Domingo J, Magpantay G, Singh S, Zhang Q, Kumaravadivel N, Bennett $\mathbf{J}$ and Khush G S 1997. Pyramiding of bacterial 
resistance genes in rice: marker aided selection using RFLP and PCR. Theor Appl Genet 95: 313-320.

IRRI 1996. Standard Evaluation System, International Rice Research Institute, Manila, Philippines.

Khanna Renu, Kaur Rupinder, Sidhu Navjot, Gill R S and Mangat G S 2014. Characterization of Elite Rice Breeding Lines for Bacterial Blight Resistance Genes using Molecular Markers In: Proceedings of National Symposium on Crop Improvement for Inclusive Sustainable Development, Nov. 7-9, 2014, Ludhiana, pp 727-729

Khush G S 2005. What it will take to feed 5.0 billion rice consumers in 2030. Pl Mol Biol 59: 1-6.

Khush G S, Mackill D J and Sidhu G S 1989. Breeding rice for resistance to bacterial blight. In: IRRI (ed) Bacterial blight of rice. IRRI, Manila, Philippines, Pp 207217.

Loan L C, Ngan V T T and Du P V 2006. Preliminary evaluation on resistance genes against rice bacterial blight in Can Tho Province- Vietnam. Omonrice 14: 44-47.

Mangat G S, Kaur Rupinder, Lore J S, Kaur Jasdeep, Sidhu Navjot and Khanna R. 2012. Molecular characterization of elite rice breeding lines for bacterial blight resistance genes. In: Sandhu S.K., Navjot Sidhu and Allah Rang (eds). International Conference on Sustainable Agriculture for Food and Livelihood Security, November 27-29, Crop Improvement Society of India, pp 125126

Mew T W, Vera Cruz C M and Medalla E S 1993. Changes in race frequency of Xanthomonas oryzae $p v$. oryzae in response to rice cultivars planted in the Philippines. Pl Dis 76: 1029-1032.

Mohan M, Nair S, Bhagwant A, Kriishna T G, Yano M, Bhatia C R and Sasaki T
1997. Genome mapping, molecular markers and markers assisted selection in crop plant. Mol Breed 3: 87-103.

Naveed S A, Babar M, Arif A, Zafar Y, Sabar M, Ali L, Chrag M, and Arif M. 2010. Detection of bacterial blight resistant gene xa5 using linked marker approaches. Afri J Biotechnol 9: 35493554.

Ou S H 1985. Rice Disease. 2d ed, Common wealth Mycological Institute, Kew, England p380.

Perumalsamy S, Bharani M, Sudha M, Nagarajan P, Arul L, Saraswathi R, Balasubramanian $\mathrm{P}$ and Ramalingam $\mathrm{J}$ 2010. Functional marker-assisted selection for bacterial leaf blight resistance genes in rice (Oryza sativa L.). Pl Breed 129: 400-406.

Raina G L, Sidhu G S and Saini R K 1981. Rice bacterial blight status in Punjab. Int Rice Res Newsl 6: 12.

Rajpurohit D, Kumar R, Kumar M and Paul P 2011. Pyramiding of two bacterial blight resistance and a semidwarfing gene in Type 3 Basmati using markerassisted selection. Euphytica 178: 111126.

Ramalingm J, Vera C C M, Kukereja K, Chittoor J M, Wu J L, Lee $\mathrm{S}$ W, Baroidan M, George M L, Cohen M, Hulbert S H, Leach J E and Leung $\mathrm{H}$ 2001. Candiate resistance genes from rice, barley and maize and their quantitative resistance in rice. $\mathrm{Mol} \mathrm{Pl}$ Micro Interact 16:14-24.

Sanchez A C, Ilag L L, Yang D, Brar D S, Ausubel F, Khush G S, Yano M, Sasaki T, Li Z and Huang N 1999. Genetic and physical mapping of $x a 13$ a recessive bacterial blight resistance gene in rice. Theor Appl Genet 98:1022-1028.

Siddiq E A 1993. Rice transformation strategy for 21st Century. Oryza 30: 186-196.

Singh Kuldeep, Mangat G S, Kaur Rupinder, Vikal Yogesh, Bhatia Dharminder, 
Singh Naveen and Bharaj T S 2014a. Punjab Basmati 3: a bacterial Blight resistant dwarf version of basmati rice variety Basmati 386. J Res Punjab Agric Univ 51: 206-207.

Singh N, Khanna R, Kaur R, Lore J S, Neelam K, Rani N S, Mangat G S and Singh K 2014b. Evaluation of aromatic rice germplasm against emerging pathotypes of Xanthomonas oryza pv.oryzae causing bacterial blight in Punjab. In: Proceedings of National Symposium on Crop Improvement for Inclusive Sustainable Development, pp 314-315.

Singh R, Bansal U K, Shukla K K and Saini R G 2004. Sources of bacterial leaf blight and white backed plant hopper resistance in aromatic rices. Crop Improv 31: 165-169.

Sombunjitt Siriporn, Sriwongchai Tanee, Kuleung Chatuporn, Hongtrakul Vipa 2017. Searching for and analysis of bacterial blight resistance genes from Thailand rice germplasm. Agriculture and Natural Resources 51: 365-375.

Suh J P, Jeung J U, Noh T H, Cho Y C, Park S H, Park H S, Shin M S, Chung-Kon Kim C K and Jena K K 2013. Development of breeding lines with three pyramided resistance genes that confer broad-spectrum bacterial blight resistance and their molecular analysis in rice. Rice 6: 1-11.

Suh J P, Noh T H, Kim K Y, Kim J J, Kim Y G, Jena K K 2009. Expression levels of three bacterial blight resistance genes against K3a race of Korea by molecular and phenotype analysis in japonica rice (O. sativa L.). J Crop Sci Biotechnol 12: 103-108.

Sumithra M, Jessica H, Jack B, Jonathan S, Daniel G, Dipika M, Shane P, Peter $\mathrm{H}$, et al., 2012. Rice Fortification: an emerging opportunity to contribute to the elimination of vitamin and mineral deficiency worldwide. Food Nutr Bull, 33: 296-307.

Sun X, Yang Z, Wang S, Zhang Q 2003. Identification of a 47-kb DNA fragment containing Xa4, a locus for bacterial blight resistance in rice. Theor Appl Genet 106: 683-687.

Sundaram R M, Vishnupriya M R, Biradar S K, Laha G S, Reddy G A, Rani N S, Sharma N P and Sonti R V 2008. Marker assisted introgression of bacterial blight resistance in Samba Mahsuri, an elite indica rice variety. Euphytica 160: 411-422.

Wang Z, Taramino G, Yang D, Liu G, Tingey S V, Miao G H and Wang G L 2001. Rice ESTs with disease-resistance gene or defense-response gene-like sequences mapped to regions containing major resistance genes or QTLs. Mol. Genet. Genomics 265: 302-310.

Zhang G, Angeles E R, Abenes M L P, Khush G S and Huang N 1998. RAPD and RFLP mapping for bacterial blight resistance gene $x a 13$ in rice. Theor Appl Genet 93: 65-70.

\section{How to cite this article:}

Narinder Singh, Renu Khanna, Kumari Neelam, Meenakshi Mittal, Jagjit Singh Lore, Rupinder Kaur and Kuldeep Singh. 2019. Molecular Analysis of Selected Aromatic Rice Germplasm Lines for Known Bacterial Blight Resistance Genes. Int.J.Curr.Microbiol.App.Sci. 8(03): 13131320. doi: https://doi.org/10.20546/ijcmas.2019.803.155 